\title{
WORKPLACE NOISE EXPOSURE AFTER MODERNISATION OF AN ALUMINIUM PROCESSING COMPLEX
}

\author{
Jagoda DOKO-JELINIĆ ${ }^{1}$, Jela LUKIĆ², Ružica UDOVIČIĆ ${ }^{2}$, Eugenija ŽUŠKIN ${ }^{1}$, \\ Iskra Alexandra NOLA ${ }^{1}$, and Zdenko ZAJEC ${ }^{3}$ \\ Andrija Štampar School of Public Health, Zagreb, Croatial, Aluminij d.d. Mostar, Mostar, Bosnia and Herzegovina ${ }^{2}$, \\ Dr Andrija Štampar Institute of Public Health ${ }^{3}$, Zagreb, Croatia
}

Received in July 2008

Accepted in April 2009

\begin{abstract}
The aim of this study was to assess to which extent modernisation of an aluminium production complex reduced occupational noise hazard for jobs with the highest potential of exposure. Periodical measurements of noise level were taken at the same workplaces using the same method, before and after modernisation of all plants. The results were compared with the recommended standard. After modernisation, the noise was significantly reduced in all sections of all plants. The greatest reduction was measured in the foundry. After modernisation, the portion of workplaces with excessive noise level dropped significantly (chisquare $=21.315 ; \mathrm{p}<0.0001$ ) from $78.4 \%$ to $13 \%$. Noise remained a problem in ingot casting and dross skimming section. In the anode plant, noise remained a problem in the green mill section where noise intensities generated by mills and vibrocompactors varied from $95 \mathrm{~dB}(\mathrm{~A})$ to $102 \mathrm{~dB}(\mathrm{~A})$. In the electrolysis plant, the portion of workplaces with extensive noise dropped from $77.8 \%$ to $39.3 \%$ after modernisation $(\mathrm{p}=0.0019)$. Noise remains to be a problem at the anode covering section where levels rise up to $100 \mathrm{~dB}(\mathrm{~A})$. The modernisation of the factory has considerably reduced the noise level in the working environment of all plants, but it can not be reduced completely.
\end{abstract}

KEY WORDS: anode manufacture, electrolysis, foundry, occupational exposure

Noise is the most pervasive hazardous agent at workplaces $(1,2)$. Excessive noise is a global occupational health hazard with considerable social and physiological impacts, including noise-induced hearing loss (NIHL) $(3,4)$. It is estimated that approximately 600 million workers are exposed to occupational noise worldwide (5). In most developing countries, industrial noise levels are higher than those in the developed countries (6).

Noise-induced hearing loss is one of the most common of all industrial diseases (3). Generally, NIHL is a sensor-neural hearing deficit which begins at higher frequencies $(3,000 \mathrm{~Hz}$ to $6,000 \mathrm{~Hz})$ and develops gradually as a result of chronic exposure to excessive sound levels (7). Although NIHL is permanent, irreversible and frequent, it is preventable
(8). Occupational hearing loss resulting from exposure to high noise levels depends not only on exposure time, but also on the frequency, intensity, and type of noise. Individual susceptibility to NIHL varies greatly, but the reason why some persons are more resistant to it while others are more susceptible is not well understood (9). Hearing loss that occurs over time is not always easy to recognise and unfortunately, most workers do not realise they are losing their hearing until it becomes permanently damaged. Likewise, NIHL can affect the quality of life in workers and cause problems such as depression and an increased risk of accidents $(10,11)$.

In addition to hearing impairment, exposure to noise has a series of health effects, such as annoyance, hypertension, disturbance of psychosocial well- 
being and psychiatric disorders. $(12,13)$. Some epidemiological studies have shown that chronic noise exposure may constitute a risk factor for cardiovascular diseases $(14,15)$. Extensive noise at workplaces can increase the risk of accidents caused by human error, as it masks sound alarms and verbal communication (16). During the last few decades, better understanding of the effects of noise on hearing has lead to adoption of minimum standards for noise exposure and to law limits of noise exposure in many countries.

Primary aluminium production is one of the largest industries in the world today. This industry directly employs over a million people worldwide and indirectly generates four times as many jobs in downstream and service industries (17). The process reducing alumina to aluminium and transforming aluminium ingots into end products has not changed significantly over past hundred years. Working conditions have changed as a result of technical improvements that greatly reduced the physical strain and exposure to air contaminants and physical agents (18). However, in all phases of aluminium production, workers are still exposed to numerous chemical and physical hazards. At some workplaces noise has been identified to exceed $90 \mathrm{~dB}(\mathrm{~A})$ and is often the greatest near pneumatic tools and mobile equipment. The most significant exposure was measured in bauxite mining. In addition to mining, noise is a significant health risk in aluminium smelting and casting operations. Casting operations include conventional ingot casting facilities in an aluminium smelter and specialised foundries. Noise can be produced by fixed sources (e.g. ventilators, compressors, generators, and electrical transmission lines) or mobile sources (e.g. trucks and trains).

In this study, we compared noise intensity in the working environment before and after modernisation of an aluminium processing complex Aluminij d.d. in Mostar, Bosnia and Herzegovina. In addition, we categorised production stages in all plants with potential for occupational noise exposure. The obtained data can be used to improve safety at work.

\section{MATERIALS AND METHODS}

\section{Plant modernisation}

Primary aluminium production is an important industry in Bosnia and Herzegovina. Aluminij d.d. Mostar starts its aluminium and aluminium alloy production electrolysis of alumina to produce liquid aluminium and in the complex consists of the following production plants: anode plant, electrolysis, and foundry (19). Aware that old technology could not compete with other aluminium manufacturers, company management has modernised all plants.

Modernisation of the anode plant included computerised dosing of coal tar pitch, replacement of the fire lead system, and control of the anode baking process. For that purpose, new chambers were built in the anode furnace, a new process of alumina mixing was introduced to rod treatment, the crane for cleaning anode butts from electrolytic cells was modernised, and semi-automatic equipment was introduced for cleaning grey cast-iron. All sections of the plant are semi-automated and several diesel vehicles are used to transport material. The factory has its own anode production with annual capacity of 130,000 tons of green anodes and 60,000 tons of baked anodes (20).

With the introduction of a technique of point feeding alumina and aluminium fluoride into the pots, computerised management, computerised control, and supervision of all parameters, the electrolysis plant is now the most advanced production plant of liquid aluminium in the region. The new system of filtration and replaceable covers on pots significantly reduce gas pollutants and exposure to physical agents, noise in particular.

Modernisation of the foundry included reconstruction of furnaces for the reception and preparation of liquid metal, new closing system for the furnace door without water cooling elements, new casting billets technology with a modified adding machine that enables three casting options, technology for cast slabs, new machine for small aluminium beam casting, rolling mill for Al-wire production, and treatment of butts. This enables the production of more tons of billets per year.

Today, thanks to modern technology, Aluminij d.d. Mostar with its 970 employees has become the largest and technologically most advanced aluminium manufacturer in the Southeast Europe, with annual production of 125,000 tons of high-quality aluminium, of up to $99.9 \%$ purity (21).

\section{Measurements}

Mandatory periodical measurements of noise levels in the working environment in all plants were taken before and after its modernisation. The aim was to identify working areas or jobs where noise exposure exceeded $90 \mathrm{~dB}(\mathrm{~A})$ (22). All measurements were taken 
at the same workplaces during shifts in the presence of workers for five days. The results were then compared with the recommended standard (22). The effect of modernisation on noise levels was estimated by comparing the measurements from before and after modernisation.

\section{Noise}

Noise at the workplace was measured using a calibrated sound level meter DELTA OHM type HD 9020, (Delta Ohm, Padova, Italy) at the ear level, set on A-weighting and slow response. As sound level meters measure sound intensity at one point in time, noise was measured at different times during work shifts to estimate noise exposure during a workday. Mean values of all measurements for each workplace $\left(\mathrm{L}_{\text {Aeq.8h }}\right)$ in the plants over five days were taken as probable value of real-time measurement. The measured values $[\mathrm{dB}(\mathrm{A})]$ were then compared with recommended standards $(22,23)$. According to standards for Bosnia and Herzegovina, the recommended exposure limit (REL) for occupational noise exposure is $90 \mathrm{~dB}$, Aweighted, as an 8-hour time-weighted average (TWA). Exposures at and above this level are considered hazardous.

\section{Statistical methods}

The chi-square test and Fisher's exact test were used to test differences between the measurements before and after the plants were modernised. The level of $p<0.05$ was considered statistically significant. All statistical analyses were performed with Statistical Package for Social Science (SPSS) 11.

\section{RESULTS}

Noise intensity was determined at 104 workplaces before and at 136 workplaces after the modernisation of all plants. Tables 1 and 2 show the results of measurements for the anode, electrolysis, and foundry before and after modernisation.

In the anode plant, noise level before modernisation exceeded the recommended standard at $78.0 \%$ of workplaces. The overall noise levels ranged from 61 $\mathrm{dB}(\mathrm{A})$ to $116 \mathrm{~dB}(\mathrm{~A})$ in all sections. In the green-mill section it exceeded $90 \mathrm{~dB}(\mathrm{~A})$ at $95 \%$ of workplaces. The highest noise levels were measured at the mills [116 dB(A)], vibro compactors [108 dB(A)], crushers [100 dB(A)], and mixers [99 dB(A)]. The noise level in two other sections, that is, anode baking furnaces and anode rodding room varied from $76.0 \mathrm{~dB}(\mathrm{~A})$ to $102 \mathrm{~dB}(\mathrm{~A})$ and from $61.0 \mathrm{~dB}(\mathrm{~A})$ to $94.5 \mathrm{~dB}(\mathrm{~A})$, respectively.

After modernisation, the number of workplaces where noise exceeded the national standard [90 $\mathrm{dB}(\mathrm{A})]$ dropped significantly $(\mathrm{p}<0.0001)$. The greatest reduction was recorded in the anode rodding room, where noise level higher than $90 \mathrm{~dB}(\mathrm{~A})$ was measured only at one workplace. Noise in the green mill, generated by mills and vibro compactors, still varied between $95 \mathrm{~dB}(\mathrm{~A})$ and $102 \mathrm{~dB}(\mathrm{~A})$.

In the electrolysis plant, noise levels ranged between $67 \mathrm{~dB}(\mathrm{~A})$ and $108 \mathrm{~dB}(\mathrm{~A})$, and excessive noise was measured at $77.8 \%$ of workplaces before modernisation. The highest noise levels were measured at anode covering and dross skimming where they varied from $84 \mathrm{~dB}(\mathrm{~A})$ to $108 \mathrm{~dB}(\mathrm{~A})$. After modernisation, noise was significantly reduced $(p=0.0019)$, exceeding the standard at $39.3 \%$ of workplaces. Noise remained to be a problem at anode covering anode with levels up to $100 \mathrm{~dB}(\mathrm{~A})$.

Before the foundry was modernised, noise levels higher than $90 \mathrm{~dB}(\mathrm{~A})$ were measured at $78.4 \%$ of workplaces in all of the following sections: ingot casting, billets casting, and wire production. In the wire production section the highest level measured was $102 \mathrm{~dB}(\mathrm{~A})$. After modernisation, the number of workplaces with excessive noise level dropped to only $13 \%$ (chi-square $=21.315 ; \mathrm{p}<0.0001$ ). Noise exposures ranged from $63 \mathrm{~dB}(\mathrm{~A})$ to $94 \mathrm{~dB}(\mathrm{~A})$. Noise remained the problem in ingot casting and dross skimming.

\section{DISCUSSION}

After modernisation, exposure to noise in Aluminij d.d. Mostar decreased significantly. The portion of workplaces where noise intensity exceeded the recommended levels dropped from $78.9 \%$ to $25.0 \%$. This increased safety at work in all plants. However, noise remained a problem at some workplaces. Our results are comparable with working conditions in most modern aluminium factories in the world (24, 25).

The greatest reduction was achieved in the foundry, where the portion of workplaces with excessive noise dropped more than $60 \%$. A research in four aluminium foundries in the US and seven in Canada confirms that it is difficult to eliminate excessive noise from these workplaces $(25,26)$. 
Table 1 Noise level in Aluminij d.d. Mostar plants by sections

\begin{tabular}{lcccccccc}
\hline \multirow{2}{*}{ Plant/section } & \multicolumn{9}{c}{ Before modernisation } & \multicolumn{2}{c}{ After modernisation } & \\
\cline { 2 - 7 } & \multicolumn{2}{c}{$\mathbf{L}_{\text {Aeq }}$} & $\mathbf{N}$ & $\mathbf{n ~ ( \% )}$ & $\mathbf{L}_{\text {Aeq }}$ & $\mathbf{N}$ & $\mathbf{n ~ ( \% )}$ & p value \\
\hline Anode plant & & & & & & & & \\
Total & 61.0 to 116.0 & 41 & $32(78.0)$ & 67.0 to 112.0 & 85 & $19(22.4)$ & $<0.0001^{*}$ \\
Green mill & 75.5 to 116.0 & 20 & $19(95.0)$ & 69.0 to 112.0 & 45 & $14(31.1)$ & $0.001^{* *}$ \\
Anode baking furnace & 76.0 to 102.0 & 9 & $7(77.8)$ & 72.0 to 93.0 & 13 & $3(23.1)$ & $0.0274^{* *}$ \\
Anode rodding room & 61.0 to 94.5 & 12 & $6(50.0)$ & 67.0 to 93.9 & 27 & $1(3.7)$ & $0.0016^{* *}$ \\
\hline Electrolysis & & & & & & & \\
Total & 67.0 to 108.0 & 27 & $21(77.8)$ & 62.0 to 102.0 & 28 & $11(39.3)$ & $0.0019^{*}$ \\
Anode changing & 82.5 to 92.5 & 7 & $4(57.1)$ & 80.0 to 82.5 & 6 & $0(0)$ & $0.0699^{* *}$ \\
Covering of anode & 100.0 to 108.0 & 9 & $9(100)$ & 98.9 to 102.0 & 9 & $9(100)$ & - \\
Metal removal tapping & 80.9 to 90.3 & 4 & $2(50.0)$ & 78.0 to 80.0 & 4 & $0(0)$ & $0.4286^{* *}$ \\
Skimming of dross & 84.0 to 93.0 & 5 & $3(60.0)$ & 83.0 to 90.5 & 5 & $2(40.0)$ & $1.000^{* *}$ \\
\hline Foundry & & & & & & & \\
Total & 83.5 to 102.0 & 37 & $29(78.4)$ & 63.9 to 94.2 & 23 & $4(13.0)$ & $<0.0001^{*}$ \\
Line for ingot casting & 85.2 to 99.8 & 8 & $7(87.5)$ & 83.0 to 94.2 & 4 & $1(25.0)$ & $0.0667^{* *}$ \\
Rolling-mill for wire & 85.8 to 102.0 & 7 & $5(71.4)$ & 65.0 to 80.0 & 4 & $0(0)$ & $0.0606^{* *}$ \\
Billets casting & 84.5 to 101.0 & 10 & $7(70.0)$ & 63.0 to 94.0 & 11 & $2(18.2)$ & $0.0300^{* *}$ \\
\hline
\end{tabular}

$L_{\text {Aeq }}=$ time-averaged equivalent noise exposure levels

$N \stackrel{\text { Aeq }}{=}$ number of workplaces

$n=$ number of workplaces with noise above REL

$R E L=$ recommended exposure limit for occupational noise exposure

$*=$ chi-square test

** = Fisher's exact test

Table 2 Time-weighted average by sections

\begin{tabular}{lcccc}
\hline Plant/section & \multicolumn{2}{c}{ Before modernisation } & \multicolumn{2}{c}{ After modernisation } \\
\cline { 2 - 5 } & n & TWA & n & TWA \\
\hline Anode plant & & 112.0 & 14 & 98.5 \\
Green Mill & 19 & 98.2 & 3 & 92.5 \\
Anode baking furnace & 7 & 94.0 & 1 & 93.9 \\
Anode rodding room & 6 & & & \\
Electrolysis & & 91.4 & 0 & - \\
Anode changing & 4 & 106.8 & 9 & - \\
Covering of anode & 9 & 85.6 & 0 & 86.7 \\
Metal removal tapping & 2 & 92.4 & 2 & 94.2 \\
Skimming of dross & 3 & & & - \\
\hline Foundry & & 98.6 & 1 & 92.4 \\
Line for ingot casting & 7 & 99.5 & 0 & \\
Rolling-mill for wire & 5 & 97.6 & 2 & \\
Billets casting & 7 & &
\end{tabular}

$n=$ number of workplaces with noise above REL

$T W A=$ time-weighted average

$R E L=$ recommended exposure limit for occupational noise exposure

Noise levels were also successfully reduced in the anode plant. The best results were achieved in the anode rodding room, where excessive noise was measured at one workplace alone. Noise remained to be a problem in the green mill.
Point feeding system and computerised control considerably reduced excessive noise in prebake potrooms. Jobs such as anode changing and metal removal tapping were no longer a health hazard. Exposure to noise levels of up to $100 \mathrm{~dB}(\mathrm{~A})$ remained 
to be a problem in anode covering. Generally, current safety technology in aluminium processing makes it is impossible to reduce noise in all of its segments $(26,27)$.

Quantitative and qualitative knowledge of exposure to noise in the working environment is fundamental for investigating and establishing an association between hearing loss and exposure, because noise is one of the most widespread occupational hazards (28). However, in addition to noise measurement at the workplace, it is important to measure personal exposure to noise. This could be considered a limitation of our study, as we did not measure individual noise exposure after hours. Designs of future similar studies should take into account after-hour noise exposure.

According to work safety guidelines, employees have to wear protective gear, headphones or ear plugs if they are exposed to high noise levels. Another step in protecting their health $(29,30)$ is specialist medical examination once a year. With annual audiometric testing, it is possible to detect changes in hearing ability before clinically significant hearing loss develops.

\section{REFERENCES}

1. Niland J, Zenz C. Occupational hearing loss, noise and hearing conservation. In: Zenz C, Dickerson O, Horvarth E, editors. Occupational Medicine. $3^{\text {rd }}$ ed. St. Louis (MO): Mosby Publication; 1994. p. 258-96

2. Rabinowitz PM, Rees TS. Occupational hearing loss. In: Rosenstock L, Cullen MR, Brodkin CA, Redlich CA, editors. Textbook of clinical occupational and environmental medicine. $2^{\text {nd }}$ ed. Oxford: Elsevier; 2005. p. 426-34.

3. Fletcher JL, Chandler DW. Comparison of occupational hearing losses among military engineers and their civilian counterparts. J Aud Res 1983;23:241-50.

4. Alleyne BC, Dufresne RM, Kanji N, Reesal MR. Costs of workers' compensation claims for hearing loss. J Occup Med 1989;31:134-8.

5. Alberti PW. Noise-the most ubiquitous pollutant. Noise Health 1998;1:3-5.

6. Nelson DI, Schwela D. Foreword. In: Goelzer B, Hanson $\mathrm{CH}$, Sehrndt GA editors. Occupational exposure to noise evaluation, prevention and control. Special Report S 64 Dortmund and Berlin: Federal Institute for Occupational Safety and Health; 2001. p. 19-20.

7. Occupational noise-induced hearing loss. ACOM Noise and Hearing Conservation Committee. J Occup Med 1989;31:996

8. Berger EH, Driscoll DP, Royster JD, Layne M. The Noise Manual. $5^{\text {th }}$ ed. Washington (DC): AIHA Press; 2000.

9. Ward WD. Endogenous factors related to susceptibility to damage from noise. Occup Med 1995;10:561-75.

10. Hétu R, Getty L, Quoc HT. Impact of occupational hearing loss on the lives workers. Occup Med 1995;10:495-512.

11. Zwerling C, Whitten PS, Davis CS, Sprince NL. Occupational injuries among workers with disabilities: the National Health Interview Survey, 1985-94. JAMA 1997:278;2163-6.
12. Borchgrevink HM. Does health promotion work in relation to noise? Noise Health 2003;5:25-30.

13. Lusk SL. Preventing noise-induced hearing loss. Nurs Clin North Am 2002;37:257-62.

14. Marcellini L, Rosati MV, Ciarrocca M, Ursini A, Tomao E, Tomei F. Lavoro agricolo: esposizione a rumore ed effetti cardiovascolari [Agricultural work: noise exposure and cardiovascular effects, in Italian]. G Ital Med Lav Ergon 2003;25(Suppl. 3):229-30.

15. Melamed S, Kristal-Boneh E, Froom P. Industrial noise exposure and risk factors for cardiovascular disease: findings from the CORDIS study. Noise Health 1999;1:49-56.

16. Melamed S, Luz J, Green MS. Noise exposure, noise annoyance and their relation to psychological distress, accident and sickness absence among blue-collar worker. The CORDIS study. Isr J Med Sci 1992;28:629-35.

17. International Aluminium Institute (IAI). The aluminium industry's sustainable development report. [displayed 9 April 2009]. Available at http://www.world-aluminium.org/?pg=/ Downloads/Publications/Full\%20Publication\&path=268.

18. Kelly JW. Overview of health issues for the past twenty-five years in the aluminium industry. In: Priest ND, O'Donnell $\mathrm{TV}$, editors. Managing health in the aluminium industry. London: Middlesex University Press; 1999. p. 1-7.

19. Doko Jelinić J, Mustajbegović J, Žuškin E, Lukić J, Ćavar $\mathrm{V}$, Ivanković A. Managing occupational safety and health in aluminium production factory, Mostar, Bosnia and Herzegovina. Croat Med J 2005;46:838-47.

20. Doko Jelinić J, Lasić I, Nola IA, Žuškin E, Ramić S. Hazardous agents in anode manufacture. Arh Hig Rada Toksikol 2008;59:73-80.

21. Aluminij today [displayed 9 April 2009]. Available at http:// www.aluminij.ba/About_us-Aluminij today.htm.

22. Pravilnik o najvišim dopuštenim razinama buke $\mathrm{u}$ sredini $\mathrm{u}$ kojoj ljudi rade i borave [Regulations for maximum allowed noise levels in working and living environment, in Croatian]. Narodne novine 37/1990.

23. Pravilnik o najvišim dopuštenim razinama buke u sredini $u$ kojoj ljudi rade i borave [Regulations for maximum permitted noise levels in an workplace and living environments, in Croatian]. Službeni list SFRJ 29/1971.

24. Priante E, Marcuzzo G, Gori G, Bartolucci GB. The occupational risk in the company producting aluminum alloy wheels. Med Lav 1992;83:451-64.

25. Korczynski RE. Occupational health concern in the welding industry. Appl Occup Environ Hyg 2000;15:936-45.

26. Daniell WE, Swan SS, McDaniel MM, Stebbins JG, Seixas NS, Morgan MS. Noise exposure and hearing Conservation practices in an industry with high incidence of workers' compensation claims for hearing loss. Am J Ind Med 2002:42:309-17.

27. Zakaria AM, Noweir KH, El-Maghrabi G. Evaluation of occupational hazards in foundries. J Egypt Public Health Assoc 2005;80:433-62.

28. Nelson DI, Nelson RY, Concha-Barrientos M, Fingerhut M. The global burden of occupational noise-induced hearing loss. Am J Ind Med 2005;48:446-58.

29. Zakon o zaštiti na radu [Occupational safety law, in Croatian]. Službeni list SR BiH 22/1990.

30. Pravilnik o načinu i postupku vršenja periodičkih pregleda i ispitivanja iz oblasti zaštite na radu [Regulations on the periodical checkup procedure and testing in occupational safety area, in Croatian]. Službeni list SR BiH 2/1991. 


\section{Sažetak}

\section{PROCJENA UTJECAJA MODERNIZACIJE I NOVIH TEHNOLOŠKIH PROCESA NA IZLOŽENOST BUCI U ALUMINIJSKOJ INDUSTRIJI}

Cilj je rada procijeniti utjecaj modernizacije tehnološkog procesa proizvodnje aluminija na prisutnost i razinu buke štetne za zdravlje radnika u radnom okolišu. U tu svrhu uspoređivani su rezultati periodičkih mjerenja razine buke prije i nakon modernizacije. Mjerenja intenziteta buke provedena su na istim radnim mjestima i istom metodom tijekom radnih smjena i uspoređeni s važećim nacionalnim standardom. Nakon modernizacije tvornice u svim odjelima proizvodnih pogona značajno se smanjila razina buke, kao i broj radnih mjesta na kojima su radnici izloženi prekomjernoj buci. Najbolji rezultati postignuti su u ljevaonici, gdje se broj radnih mjesta s prekomjernom razinom buke, tj. razinom buke višom od $90 \mathrm{~dB}(\mathrm{~A})$ smanjio sa $78.4 \%$ na $13 \%$. Na radnim mjestima gdje se izlijevaju ingoti i skida šljaka buka je i dalje prekomjerna. U pogonu anoda prekomjerna je buka i dalje prisutna pri proizvodnji sirovih anoda, gdje razina buke zbog rada mlinova i vibrokompresora varira od $95 \mathrm{~dB}(\mathrm{~A})$ do $102 \mathrm{~dB}(\mathrm{~A})$. U pogonu elektrolize buka viša od 100 $\mathrm{dB}(\mathrm{A})$ izmjerena je pri zasipanju anoda. Iako je modernizacijom tvornice i unaprjeđenjem tehnološkog procesa značajno reducirana razina buke, nije ju moguće u cijelosti ukloniti.

KLJUČNE RIJEČI: elektroliza, ljevaonica, profesionalna izloženost, proizvodnja anoda

\section{CORRESPONDING AUTHOR:}

Professor Jagoda Doko Jelinić, PhD

Andrija Štampar School of Public Health

Rockefellerova 4, 10000 Zagreb, Croatia

E-mail:jdoko@snz.hr 